\title{
SUSTAINABLE E-LEARNING ENGAGEMENT AND LEARNING SATISFACTION IN ONLINE BIOLOGY EDUCATION
}

\author{
Orland Jae C. Jerusalem ${ }^{1}$, Dr. Ronald S. Decano ${ }^{2}$ \\ ${ }^{1}$ Graduate Student, Master of Arts in Teaching Major in Biology, Davao del Norte State College \\ ${ }^{2}$ Dean, Institute of Advanced Studies, Davao del Norte State College
}

Article DOI: https://doi.org/10.36713/epra9174

DOI No: 10.36713/epra9174

\begin{abstract}
This study was set out to determine the sustainable e-learning engagement and the level of learning satisfaction of science, technology, engineering, and mathematics (STEM) students at The Rizal Memorial Colleges, Inc. This study employed a descriptive-correlational research method and used Mean and Pearson $r$ for the data analysis. This study was conducted in the Integrated Basic Education Department of The Rizal Memorial Colleges, Inc., with a non-probability purposive sampling technique to identify the respondents. The respondents of this study were Grade 11 and Grade 12 STEM students who are currently enrolled in this academic year to answer the set questions about their sustainable e-learning engagement and the level of learning management. On the other hand, the questionnaire was validated by three experts to ensure the validity and reliability of the questions. Furthermore, the study revealed that sustainable e-learning engagement and learning satisfaction have a positive relationship.
\end{abstract}

KEYWORDS: charismatic leadership, ethical practices, working relationships, engaging environment.

\section{INTRODUCTION}

In the past decade, online education has experienced dramatic growth. The threats of the COVID-19 epidemic we confront are becoming more intertwined as the globe grows more interconnected. The global lockdown of education institutions caused major interruptions in students' learning, and it has impacted people of all nationalities, educational levels, income levels, and genders. Several educational institutions revered the opening of classes and shifted in a new calendar. Such transitions also affect the mode of instructional delivery that greatly changes the framework of most institutions to maintain their pursuit of quality education. When teaching is moving online, assessments shifted too. Government and civic societies are still in the process of working together to mobilize resources and expertise to overcome COVID-19's impact on education.

Conventional schooling has been disrupted around the world, including widespread school closures resulting from the lockdowns in response to COVID-19 (Schleicher, 2020). According to the United Nations Educational, Scientific, and Cultural Organization (UNESCO), governments worldwide have shuttered schools, impacting over 1.5 billion students and accounting for more than $91 \%$ of total enrollment (Vegas, 2020). With this impact, it has stimulated innovation within the education sector. Educational sectors continuously improve their innovative approaches in education and training continuity. However, these shifts have revealed that the bright future of learning and the rapid changes in modes of delivering high-quality education is inextricably linked to the imperative of leaving no one behind (United Nations, 2020). In a comparison made by Foerderer, Hoffman, Schneider, and Prichard (2021), students could choose their courses based on learning preference, while instructors could choose a 
teaching modality that reflected their comfort and skill with online technology. When the pandemic hovers the globe, teachers make the switch from face-to-face classes to emergency remote learning while students face problems with limited access to necessary resources for online learning, like the regular use of a computer, reliable Wi-Fi, and a printer. Foerderer et al. (2021) reported a reduced student satisfaction rate. Instructors' lack of readiness for online course delivery was highlighted by students in light of the reducing learning satisfaction of the students.

When the conventional way of teaching shifted to online, the E-learning framework was increasingly used (Gopal, Singh \& Aggarwal, 2021). Student engagement in E-learning classes allows learners to actively engage in learning anytime and anywhere, leading to favorable learning outcomes such as a high level of learning achievement and higher-order thinking abilities (Lee, Song \& Hong, 2019). Attending virtual sessions and real-time conference call classes are the most preferred mode of delivery as perceived by need by the learners longing for mastery of a certain course competency (Basuony, EmadEldeen, Farghaly, Bassiouny, Mohamed, 2020). Despite acknowledged disadvantages such as feelings of isolation and technological gaps, online learning generally concludes that students can find satisfaction in this style of learning - at least as effective as face-to-face learning (Loton, Stein, Parker \& Gauci, 2020)

Among all disciplines affected by the havoc of the global crisis is the teachers' way of teaching science subjects, for one is biology. During this transition, rapid communications on innovative online teaching approaches are highly emphasized to best deliver scientific concepts through synchronous classes (Ortiz, 2020). Biology classes involving class lectures, in-class group interactions, laboratory activities, and field studies are now required to learn about the natural world from their computer screens in a socially isolating environment. However, to compensate for such disadvantages, tools and techniques that may support students engaging in remote learning should be considered (Humphrey \& Wiles, 2021).

Various researches concerning online learning situations in the world provided timely information about instructor viewpoints when required to switch coursework to an emergency remote learning paradigm. Teachers and students may have various amounts of familiarity with online course delivery and express a range of emotions in response to the sudden transition. As a result of the COVID-19 epidemic, the world of basic and higher education has changed dramatically. Thus school leadership, instructional design support employees and faculty navigate this new version of the learning experience (Standerford, Menard, Edge, Bergh, Shayter, Smith \& Vandenvond, 2020).

\section{METHODOLOGY \\ Research Design}

This study will employ a non-experimental quantitative research design with a descriptive-correlation research method and with the aid of the adapted questionnaire as a tool in gathering the data. Good (2005) describe that quantitative research design is rooted in numerical approaches.

The emphasis is on objectivity and the use of statistics or data gathered through polls, questionnaires, or surveys. With quantitative research methods, numerical data are gathered and generalized across groups of people to explain trends or phenomena. Quantitative approaches are best when the need is to corporate data systematically, such as comparison between groups. Quantitative research also provides general features of a population. Quantitative research is particularly advantageous when doing a large-scale needs assessment or baseline survey on a wide scale. It is self-contained and should provide comparable findings regardless of who conducts the study (Daniel, 2016).

This design is valuable since the data is based on exact measurement applying structured and validated information collection. This approach produces a statistical report on the level of intervention that must be acted upon to address problems as mentioned in the statement that the problem is met.

\section{Research Respondents}

The respondents will be the Grade 11 and 12 Senior High School STEM students of The Rizal Memorial Colleges Inc. from the Integrated Basic Education Department. The STEM students are those who are currently enrolled in this academic year. The selection of the respondents will employ a non-probability purposive sampling technique. Purposive sampling is a type of sampling that can be used in various contexts, and it selects cases with the help of an expert's judgment or with a specific aim in mind. When a difficult-to-reach population needs to be measured, the most common method is purposeful sampling. 


\section{Research Instrument}

This study will use an adapted survey questionnaire to gather relevant answers from the respondents. The researcher will scrutinize the questionnaire to ensure alignment of the question in the given indicators per variable. There will be five questions for each indicator. The questionnaire will be divided into two parts, and the first part will be about sustainable e-learning engagement, and the second part will be about learning satisfaction.

\section{Data Gathering Procedures}

The necessary data underwent the following gathering procedure:

The researcher will ask for an endorsement letter to conduct the study from the Institute of Advanced Studies Office. A letter request attached with the endorsement letter will be presented to the Office of the Principal of The Rizal Memorial Colleges, Inc. - Integrated Basic Education Department to secure permission. An arrangement will be made regarding the conduct of the study. The researcher will have a brief discussion with the principal and Senior High School Coordinator about the aims and future directions of the research study. Since most educational institutions prohibit the entrance of visitors because of the outraging transmission COVID-19 virus, the flow of the data gathering procedures ensures that the researcher and other persons involved in this research study follows the health and sanitary standard set by the COVID-19 Inter-Agency Task Force (IATF) for the Management of Emerging Infectious Diseases such as wearing a face mask and face shield and observing physical distancing. The data was gathered, tallied, tabulated, analyzed, and interpreted accordingly with the adviser's assistance.

\section{Data Analysis}

The following statistical tools were used in the conduct of this study:

Weighted Mean will be used to answer research numbers 1, 2, and 3 to determine the level of sustainable elearning engagement and learning satisfaction of STEM students of The Rizal Memorial Colleges, Inc.

Product Moment Correlation or Pearson $R$ will be used to answer research questions 4 and 5 or to see the significant relationship between the level of sustainable e-learning engagement and learning satisfaction of STEM students of The Rizal Memorial Colleges, Inc.

\section{RESULT AND DISCUSSIONS}

Conventional schooling has been disrupted around the world, including widespread school closures resulting from the lockdowns in response to COVID-19 (Schleicher, 2020). As reported by the United Nations Educational, Scientific and Cultural Organization (UNESCO), countries around the world have closed schools nationwide, affecting over 1.5 billion learners and representing more than 91 percent of total enrolled learners (Vegas, 2020). With this impact, it has stimulated innovation within the education sector. Many schools and universities have begun to offer online courses due to the rapid development of the Internet. Traditional face-to-face training is no longer a feasible option. However, there are numerous worries and issues developed, especially regarding the quality of online education.

The Level of Sustainable E-Learning Engagement of the STEM students of The Rizal Memorial Colleges, Inc. in terms of Online Instruction

The table below shows the level of sustainable e-learning engagement of the STEM students of The Rizal Memorial Colleges, Inc. in terms of online instruction. Online instruction refers to the facilitation of a course that was created to be delivered entirely online. The majority of the time, educational experiences using an online platform are planned out over weeks or months, with the help of an instructional designer and a media services team. 
Table 1. The Level of Sustainable E-Learning Engagement of the STEM students of The Rizal Memorial Colleges, Inc. in terms of Online Instruction

\begin{tabular}{|c|c|c|}
\hline Statement & Mean & Description \\
\hline $\begin{array}{l}\text { 1. I participate in online science discussions } \\
\text { with my classmates. }\end{array}$ & 4.37 & Very High \\
\hline $\begin{array}{l}\text { 2. I like it when the teacher/lecturer } \\
\text { encourages my scientific thinking skills } \\
\text { online. }\end{array}$ & 4.34 & Very High \\
\hline $\begin{array}{l}\text { 3. I prefer it when the teacher/lecturer } \\
\text { adequately addresses my scientific questions } \\
\text { during online classes. }\end{array}$ & 4.56 & Very High \\
\hline $\begin{array}{l}\text { 4. I ask the teacher/lecturer scientific } \\
\text { questions online. }\end{array}$ & 2.78 & Moderate \\
\hline $\begin{array}{l}\text { 5. I prefer it when the teacher/lecturer } \\
\text { responds promptly to my scientific } \\
\text { questions. }\end{array}$ & 4.19 & High \\
\hline Mean & 4.05 & High \\
\hline
\end{tabular}

Table 1 shows the level of sustainable e-learning engagement of the STEM students of The Rizal Memorial Colleges, Inc. in online instruction. The mean of statement number 1, "I participate during online science discussions with my classmates," is 4.37 with a very high description indicating that the students' e-learning engagement in terms of online instruction is always evident. The mean of statement number 2 " I like it when the teacher/lecturer encourages my scientific thinking skills online" is 4.34 with a very high description indicating that students' online instruction engagement to their science class is always evident. The mean of statement number 3 " $I$ prefer it when the teacher/lecturer adequately addresses my scientific questions during online classes" is 4.56 with a description of very high indicates that the students' sustainable e-learning engagement in online instruction is always evident. The mean of statement number 4 "I ask the teacher/lecturer scientific questions online" is 2.78 with a description of moderate which directly indicates that the students' sustainable e-learning engagement in terms of online instruction is slightly practiced or sometimes evident. The mean of statement number 5 " I prefer it when the teacher/lecturer responds promptly to my scientific questions" is 4.19 with a description of high as a description indicates that the students' sustainable e-learning engagement in terms of online instruction is well-practiced and frequently evident. The mean of Table 1 is 4.05 with high as a description indicating the students' sustainable elearning engagement in terms of online instruction is well-practiced and frequently evident. It means that students' engagement in e-learning in terms of their participation in the online class is being practiced and evident.

\section{The Level of Sustainable E-Learning Engagement of the STEM students of The Rizal Memorial Colleges, Inc. in terms of Online Assessments}

The table below shows the level of sustainable e-learning engagement of the STEM students of The Rizal Memorial Colleges, Inc. in terms of online assessments. In any course, determining the efficacy of instruction requires measuring the progress students have made toward the objectives. As educators, exerting efforts in giving online assessments will ensure the best possible outcomes for the learners. Thus, Airasian \& Russell (2007) defined online assessment as the act of gathering, integrating, and evaluating data to conclude with the use of online platforms. 
Table 2. The Level of Sustainable E-Learning Engagement of the STEM students of The Rizal Memorial Colleges, Inc. in terms of Online Assessments

\begin{tabular}{|c|c|c|}
\hline Statement & Mean & Description \\
\hline $\begin{array}{l}\text { 1. I prefer it when the teacher/lecturer gives valuable } \\
\text { feedback on my assignments online. }\end{array}$ & 4.40 & Very High \\
\hline 2. I access assessment scientific information online. & 4.63 & Very High \\
\hline $\begin{array}{l}\text { 3. I prefer it when the teacher/lecturer provides me with } \\
\text { useful feedback on my work online. }\end{array}$ & 4.51 & Very High \\
\hline $\begin{array}{l}\text { 4. I like online assessments as it motivates and entices my } \\
\text { scientific thinking skills. }\end{array}$ & 4.60 & Very High \\
\hline $\begin{array}{l}\text { 5. Online assessments gives me stress in analyzing } \\
\text { scientific concepts. }\end{array}$ & 4.01 & High \\
\hline Mean & 4.43 & Very High \\
\hline
\end{tabular}

Table 2 shows the level of sustainable e-learning engagement of the STEM students of The Rizal Memorial Colleges, Inc. in terms of online assessments. The mean of statement number 1 "I prefer it when the teacher/lecturer gives valuable feedback on my assignments online" is 4.40 with a very high description indicating that the students' sustainable learning engagement terms of online assessment are always evident. The mean of statement number 2 " $I$ access assessment scientific information online" is 4.63 with a description of very high indicates that the students' sustainable e-learning in terms of online assessment is always evident. The mean of statement number 3 "I prefer it when the teacher/lecturer provides me with useful feedback on my work online" is 4.51 with a very high description indicating that the students' sustainable e-learning in terms of online assessment is always evident. The mean of statement number 4 "I like online assessments as it motivates and entices my scientific thinking skills" is 4.60 with a very high description indicating that the students' sustainable e-learning in terms of online assessment is always evident. The mean of statement number 5 "Online assessments gives me stress in analyzing scientific concepts" is 4.01 with a high description indicating that the students' sustainable e-learning in terms of online assessment is wellpracticed and frequently evident. The mean of Table 2 is 4.43 with a very high description indicates the students' sustainable e-learning in terms of online assessment is very well-practiced and very much evident. It means that STEM students tend to get favorable learning outcomes if a science activity or a test is delivered online. However, this can be stressful because of certain issues confronted by online assessments.

The Level of Sustainable E-Learning Engagement of the STEM students of The Rizal Memorial Colleges, Inc. in terms of Online Remediations

The table below shows the level of sustainable e-learning engagement of the STEM students of The Rizal Memorial Colleges, Inc. in terms of online remediations. Educators may find it beneficial to use online remediations in an implemented distance learning modality in an educational institution. Engaging students to be creative is one key factor to make online remediation successful. 
Table 3. The Level of Sustainable E-Learning Engagement of the STEM students of The Rizal Memorial Colleges, Inc. in terms of Online Remediation

\begin{tabular}{|c|c|c|}
\hline Statement & Mean & Description \\
\hline $\begin{array}{l}\text { 1. I prefer it when the teacher/lecturer helps me identify } \\
\text { problem areas during science online instructions. }\end{array}$ & 4.62 & Very High \\
\hline $\begin{array}{l}\text { 2. If I have an inquiry, I prefer the teacher/lecturer to respond } \\
\text { quickly. }\end{array}$ & 4.78 & Very High \\
\hline $\begin{array}{l}\text { 3. I want to get the same amount of help from the } \\
\text { teacher/lecturer as do other students. }\end{array}$ & 4.49 & Very High \\
\hline $\begin{array}{l}\text { 4. I prefer it when my classmates conduct an online meeting to } \\
\text { do a group study. }\end{array}$ & 4.43 & Very High \\
\hline 5. I prefer face-to-face remediation in science. & 4.29 & Very High \\
\hline Mean & 4.52 & Very High \\
\hline
\end{tabular}

Table 3 shows the level of sustainable e-learning engagement of the STEM students of The Rizal Memorial Colleges, Inc. in terms of online remediations. The mean of statement number 1 "I prefer it when the teacher/lecturer helps me identify problem areas during science online instructions" is 4.62 with a description of very high indicates that the sustainable e-learning engagement of the STEM students in terms of online remediation is always evident. The mean of statement for number 2 "If I have an inquiry, I prefer the teacher/lecturer to respond quickly" is 4.78 with a description of very high indicates that the sustainable e-learning engagement of the STEM students in terms of online remediation is always evident. The mean of statement for number 3 "I want to get the same amount of help from the teacher/lecturer as do other students" is 4.49 with a very high description indicating that the sustainable e-learning engagement of the STEM students in terms of online remediation is always evident. The mean of statement number 4 "I prefer it when my classmates conduct an online meeting to do group study" is 4.43 with a description of very high indicates that the sustainable e-learning engagement of the STEM students in terms of online remediation is always evident. The mean of statement number 5 "I prefer face-to-face remediation in science" is 4.29 with a description of very high indicates that the sustainable e-learning engagement of the STEM students in terms of online remediation is always evident. The mean of Table 3 is 4.52 with a very high description indicating that the sustainable e-learning engagement of the STEM students in terms of online remediation is always evident. It simply means that the students learning science concepts tend to draw attention in engaging themselves in online remediation classes to support the weak concepts that were not clear to the learners during their online class. In this matter, the instructor gives focused attention to the learner.

Summary on the Level of Sustainable E-learning Engagement of the STEM Students of The Rizal Memorial Colleges, Inc.

Table 4. Summary on the Level of Sustainable E-learning Engagement of the STEM Students of The Rizal Memorial Colleges, Inc.

\begin{tabular}{lcc}
\multicolumn{1}{c}{ Indicators } & Mean & Description \\
\hline 1. Online Instructions & 4.05 & High \\
2. Online Assessments & 4.43 & Very High \\
3. Online Remediations & 4.52 & Very High \\
\hline \multicolumn{1}{c}{ Overall Mean } & $\mathbf{4 . 3 3}$ & Very High \\
\hline
\end{tabular}

Table 4 summarizes the mean of the indicators in the level of sustainable e-learning engagement. The mean of the first indicator "Online Instruction" is 4.05 with a description of high indicates that the students' sustainable engagement during online instruction is well-practiced and oftentimes evident. The second indicator "Online Assessment" is 4.43 with a very high description indicating that the students' sustainable engagement during an 
online assessment is always evident. The mean of the third indicator "Online Remediation" is 4.52 with a very high description indicating that the students' sustainable engagement during online remediation is always evident. The overall mean of Table 4 is 4.33 which is very high as a description indicates that the students' sustainable e-learning engagement is always practiced. It means that the STEM students are engaged in sustainable e-learning instructions, remediations, and assessments.

Although the online education system has many advantages under normal public health conditions, the COVID-19 pandemic, which creates worry and anxiety for everyone, showcased the downsides or bad impacts of online education. The rapid transition to an online education system, together with the pandemic's effects on interpersonal interactions, will have the following negative consequences and that includes the learners' limited ability to the gadget, internet connectivity issues, Internet as a limiter of the learners' development of creativity and imagination, and absenteeism (Ionescu, et. al. 2020).

Overall, improving our understanding of long-term e-learning is beneficial. Institutional decision-making and policy decisions can be aided by developing a coherent body of information. Empirical evidence that can be generalized and applied throughout the sector could aid in addressing major financial and institutional issues. Finding a way to guide research on long-term e-learning is critical.

The Level of Learning Satisfaction of the STEM Student of The Rizal Memorial Colleges, Inc. in terms of Material Conditions and Learning Facilities

The table below shows the level of learning satisfaction of STEM students of The Rizal Memorial Colleges, Inc. in terms of the utilization of learning facilities and the instructional conditions of the material. An effective school facility and satisfying instructional conditions respond to changing instructional programs and, at the very least, provide a comfortable, safe, secure, accessible, well-lit, well-ventilated learning environment.

Table 5. The Level of Learning Satisfaction of the STEM Student of The Rizal Memorial Colleges, Inc. in terms of Material Conditions and Learning Facilities

\begin{tabular}{lcc}
\hline \multicolumn{1}{c}{ Statement } & Mean & Description \\
\hline 1. I submit assignments online (Email, Learning Management & 4.66 & Very High \\
System, or LMS). & 4.44 & Very High \\
2. I want to find out course or unit information online. & 4.50 & Very High \\
3. I read the teacher/lecturer's lesson notes online. & 4.59 & Very High \\
4. I have sufficient internet connectivity and a gadget to use in my \\
$\begin{array}{l}\text { online science class. } \\
\text { 5. I encounter glitches on the Internet and in the gadget, I use } \\
\text { during an online class. }\end{array}$ \\
\hline Mean
\end{tabular}

Table 5 shows the level of learning satisfaction of the STEM students of The Rizal Memorial Colleges, Inc. in terms of the utilization of learning facilities and the instructional conditions of the material. The mean of statement number 1 "I submit assignments online (Email, Learning Management System or LMS)" is 4.66 with a description of very high indicates that the students' learning satisfaction in terms of the utilization of learning facilities along with the instructional conditions of the material is always evident. The mean of statement number 2 "I want to find out course or unit information online" is 4.44 with a very high description indicates that the students' learning satisfaction in terms of the utilization of learning facilities and the instructional conditions of the material is always evident. The mean of statement number 3 "I read the teacher/lecturer's lesson notes online" is 4.50 with a very high description indicating that the students' learning satisfaction in terms of the utilization of learning facilities and the instructional conditions of the material is always evident. The mean of statement number 4 "I have sufficient internet connectivity and a gadget to use in my online science class" is 4.59 with a description of very high indicates that the students' learning satisfaction in terms of the utilization of learning facilities along with the instructional conditions of the material is always evident. The mean of statement number 5 "I encounter glitches on the internet and in the gadget I use during an online class" is 4.60 with a description of very high indicates that the students' learning satisfaction in terms of the utilization of learning facilities along with the instructional conditions of the 
material is always evident. The mean of Table 5 is 4.56 with a very high description indicating that the students' learning satisfaction in terms of material and learning conditions is always evident.

As a result of the COVID-19 outbreak, many universities have been forced to switch to online lecture delivery. For many teachers, however, creating outstanding online classes in a short amount of time has proven to be extremely stressful and difficult. According to Europa (2020), schools will almost certainly not return to their previous state, which is why academic facility design standards will change. Flexibility, digital communication, virtual communities, environmental laws, and overall well-being will be stressed. Although academic rooms used to be assigned to specific applications, there is now potential to offer more flexible options.

The Level of Learning Satisfaction of the STEM Student of The Rizal Memorial Colleges, Inc. in terms of Teacher and Instructional Activity

The table below shows the level of learning satisfaction of the STEM students of The Rizal Memorial Colleges, Inc. in terms of teacher and instructional activity. By structuring the interaction between teacher and students around content, instructional activities limit the range of interactions, materials, and content that a novice must manage, rather than the full range that classroom teaching demands. This provides teachers an entry point into the profession's practices in real settings and allows them to learn from teaching.

Table 6. The Level of Learning Satisfaction of the STEM Student of The Rizal Memorial Colleges, Inc. in terms of Teacher and Instructional Activity

\begin{tabular}{lcc}
\hline \multicolumn{1}{c}{ Statement } & Mean & Description \\
\hline 1. The teacher/lecturer is prompt in answering my queries online. & 4.79 & Very High \\
2. The teacher/lecturer is clear in instructing online class activities. & 4.47 & Very High \\
$\begin{array}{l}\text { 3. The teacher/lecturer uses different teaching strategies to best } \\
\text { deliver his/her topic in science. }\end{array}$ & 4.72 & Very High \\
$\begin{array}{l}\text { 4. The online class of my teacher is very enthusiastic and engaging. } \\
\text { 5. The teacher/lecturer delivers the science lesson well during an } \\
\text { online class. }\end{array}$ Mery High \\
\hline Mean
\end{tabular}

Table 6 shows the level of learning satisfaction of STEM students of The Rizal Memorial Colleges, Inc. in terms of the teacher and its instructional activity. The mean of statement number 1 "The teacher/lecturer is prompt in answering my queries online" is 4.79 with a very high description indicating that the students' learning satisfaction in terms of the teacher and its instructional activity is always evident. The mean of statement number 2 "The teacher/lecturer is clear in instructing online class activities" is 4.47 with a description of very high indicates that the students' learning satisfaction in terms of the teacher and its instructional activity is always evident. The mean of statement number 3 "The teacher/lecturer uses different teaching strategies to best deliver his/her topic in science" is 4.72 with a very high description indicating that the students' learning satisfaction in terms of the teacher and its instructional activity is always evident. The mean of statement number 4 "The online class of my teacher is very enthusiastic and engaging" is 4.57 with a very high description indicating that the students' learning satisfaction in terms of the teacher and its instructional activity is always evident. The mean of statement number 5 "The teacher/lecturer delivers the science lesson well during online class" is 4.74 with a very high description indicating that the students' learning satisfaction in terms of the teacher and its instructional activity is always evident. The mean of Table 6 is 4.66 with a very high description indicating that the students' learning satisfaction in terms of the teacher and its instructional activity is always evident. The result implies that the learners can be satisfied by their learning because the instructors use varied strategies to master competencies in science.

In the careful analysis of Yang (2017) in her study about the effectivity of instructional strategies in an online science class, she found out that participants' reflections and course assessments suggested that various instructional tactics and course design aspects helped students learn science concepts in an online setting. Case studies, video demonstrations, instructor's notes, micro-projects, and an online discussion forum were particularly beneficial. The application-focused course content, consistent structure, different resources, learning activities, and the online course design characteristics were deemed beneficial. Teaching online is not the same as teaching in a traditional 
classroom setting, and teaching online requires a different set of skills and knowledge than teaching face-to-face classes.

The Level of Learning Satisfaction of STEM Students of The Rizal Memorial Colleges, Inc. in terms of Learning Outcomes

The table below summarizes the amount of satisfaction with learning achieved by STEM students at The Rizal Memorial Colleges, Inc. Learning outcomes are statements that define the information and abilities that students should gain after a given assignment, class, course, or program and assist students in comprehending why that knowledge and skills would be beneficial to them.

Table 7. The Level of Learning Satisfaction of STEM Students of The Rizal Memorial Colleges, Inc. in terms of Learning Outcomes

\begin{tabular}{|c|c|c|}
\hline Statement & Mean & Description \\
\hline $\begin{array}{l}\text { 1. My learning during online classes is integrated into real } \\
\text { cases. }\end{array}$ & 4.59 & Very High \\
\hline $\begin{array}{l}\text { 2. I am learning different scientific concepts during online } \\
\text { classes. }\end{array}$ & 4.63 & Very High \\
\hline $\begin{array}{l}\text { 3. I can provide real-life examples from my learning during the } \\
\text { online class. }\end{array}$ & 3.65 & High \\
\hline 4. I can acquire scientific skills during our online classes. & 3.40 & High \\
\hline $\begin{array}{l}\text { 5. I can identify my strengths and develop areas for scientific } \\
\text { growth. }\end{array}$ & 4.65 & Very High \\
\hline Mean & 4.18 & High \\
\hline
\end{tabular}

Table 7 shows the level of learning satisfaction of STEM students of The Rizal Memorial Colleges, Inc. in terms of learning outcomes. The mean of statement number 1 "My learning during online classes is integrated to real cases" is 4.59 with a very high description indicating that the students' learning satisfaction in terms of learning outcomes is always evident. The mean of statement number 2 "I am learning in different scientific concepts during online classes" is 4.63 with a very high description indicating that the students' learning satisfaction in terms of learning outcomes is always evident. The mean of statement number 3 "I can provide real-life examples from my learning during the online class" is 3.65 with a description of high indicates that the students' learning satisfaction in terms of learning outcomes is well-practiced and frequently evident. The mean of statement number 4 "I can acquire scientific skills during our online classes" is 3.40 with a high description indicating that the students' learning satisfaction in terms of learning outcomes is well-practiced and frequently evident. The mean of statement number 5 "I can identify my strengths and develop areas for scientific growth" is 4.65 with a very high description indicating that the students' learning satisfaction in terms of learning outcomes is always evident. The mean of Table 7 is 4.18 with a high description indicating that the teacher's students' learning satisfaction in terms of learning outcomes is well-practiced and frequently evident. It means that the students' learning satisfaction in terms of learning outcomes is well-practiced.

The findings are consistent with a study published in Armor and Brown's Australian Academy of Science (2020). They discovered that varied learning outcomes for online versus in-class education can impact learners' performance ratings. They stated in their analysis that if current distance learning arrangements are maintained for an extended period, over half of Australian primary and secondary students will have poor educational outcomes. Students from low socioeconomic backgrounds, students who speak English as a second language, students who face special learning challenges, and students who reside in rural or remote areas are all at risk of poor academic performance. In addition to these findings, the authors discovered that (1) access to digital technology and the Internet; 2) the home learning environment and family support; and 3) teacher and student preparation and capability are all factors that influence remote learning efficacy. Other profound findings of the author pointed out that 'blended learning,' which blends face-to-face and remote learning, is as good as classroom learning for many students.

To successfully execute and complete a course/program in the new normal educational landscape, the teaching setting, learning activities, and assessment scheme must be correctly structured based on the defined 
learning outcomes to ensure that learning is authentic even if classes are virtually augmented. (Mahajan \& Singh, 2017; Mahajan \& Singh, 2017; Mahajan \& Singh, 2017).

\section{Summary on the Level of Learning Satisfaction of the STEM students of The Rizal Memorial Colleges, Inc.}

The table below summarizes the level of learning satisfaction of the Integrated Basic Education teachers in The Rizal Memorial Colleges, Inc. The established educational establishment and society have expressed concerns about the quality of online learning. Students' perceptions of their course experience are frequently used as a proxy for learning engagement in the context of satisfaction when addressing these concerns.

Table 8. Summary on the Learning Satisfaction of the STEM Students of The Rizal Memorial Colleges, Inc.

\begin{tabular}{lcc}
\hline \multicolumn{1}{c}{ Indicators } & Mean & Description \\
\hline 1. Material Condition and Learning Facilities & 4.56 & Very High \\
2. Teacher and Instructional Activity & 4.66 & Very High \\
3. Learning Outcomes & 4.18 & High \\
\hline \multicolumn{1}{c}{ Overall Mean } & $\mathbf{4 . 4 6}$ & Very High \\
\hline
\end{tabular}

Table 8 summarizes the mean of the indicators in the level of learning satisfaction. The mean of the first indicator, "Material Condition and Learning Facilities," is 4.56, with a very high description indicating that the students' learning satisfaction is always evident. The mean of the second indicator, "Teacher and Instructional Activity," is 4.66, with a very high description indicating that the students' learning satisfaction is always evident. The mean of the third indicator, "Learning Outcomes," is 4.18, with a high description indicating that the students' learning satisfaction is well-practiced and often evident. The overall mean of Table 8 is 4.52 , with a very high description indicating that the students; learning satisfaction is always evident. This means that students are satisfied with their achievement outcomes in their science class, even if it is on an online platform.

However, not all learners are fully satisfied with online distance learning, such as learning conditions or the instructional material itself, will be considered. Ghaderizefreh and Hoover (2018) stated that not all of the qualities of online learning (except for the ability to develop attention) were linked to the negative emotions of anger, anxiety, and boredom, which are the most common in online learning. The researchers have claimed that technological issues, isolation, and a lack of social support in online learning environments may influence students' experiences of negative emotions like anxiety, anger, and boredom. As a result, while creating online courses, instructors and designers should include variables that reduce negative emotions, resulting in improved learning and achievement.

Relationship Between the Level of Sustainable E-Learning Engagement and the Level Learning Satisfaction of the STEM Students of The Rizal Memorial Colleges, Inc.

The E-learning framework is becoming more popular as a dynamic platform for learning and teaching operations. Elearning is a novel approach to online learning built on information technology. The only way to find out is to look at student satisfaction and performance.

Table 9. The Significant Relationship Between the Level of Sustainable E-Learning Engagement and the Level Learning Satisfaction of the STEM Students of The Rizal Memorial Colleges, Inc.

\begin{tabular}{lccccc}
\hline \multicolumn{1}{c}{ Variables } & Mean & Std & R & $\begin{array}{c}\text { Sig. Level } \\
\boldsymbol{\alpha}<\mathbf{0 5}\end{array}$ & Decision \\
\hline 1. Sustainable E-Learning Engagement & 4.33 & .407 & .425 & .000 & ${\text { Reject } \mathrm{H}_{\mathrm{o}}}^{\text {2. Learning Satisfaction }}$ \\
\hline
\end{tabular}

Table 9 shows the significant relationship between the level of sustainable e-learning engagement and the level of learning satisfaction of the STEM students in The Rizal Memorial Colleges, Inc. The mean of the first independent variable, sustainable e-learning engagement, is 4.33 with a standard deviation of 0.407 . The dependent 
variable is learning satisfaction having a 4.46 mean and 0.433 standard deviation. The Pearson- $\mathrm{R}$ correlation result showed 0.425 which means there is a moderate positive correlation between the variables at a significant level of .000 which means a substantial relationship between sustainable e-learning engagement and learning satisfaction. It explains that if the independent variable is increasing the dependent variable will also increase. The decision is to reject the null hypothesis.

\section{CONCLUSIONS}

\section{RESULTS AND DISCUSSIONS}

Learning theory, involvement theory, engagement theory, and behavioristic approaches have all been validated in the educational context in this study, allowing for a better understanding of students' potential perceptions of using online learning platforms to improve academic achievement and satisfaction. The current study's potential contribution to online learning platforms has been examined and described. Additional information about student satisfaction and theoretical progress has also been provided. The present study underlines that incorporating online learning into modern times can influence the learner's achievement rate, not simply during pandemic periods. There are also premises of this study. The correlations between online learning satisfaction revealed that higher degrees of understandability, illustration, passion, and cultivating attention led to enhanced student satisfaction with the online learning experience. High levels of learning anticipation, on the other hand, resulted in lower course satisfaction. These findings back up prior research that revealed that the most essential element impacting students' satisfaction with online learning is course quality. Song (2004) found that the clarity of course expectations and the understandability of course objectives significantly effects satisfaction. Surprisingly, the difficulty, pace, and lack of transparency had no bearing on the happiness of these students. One reason course difficulty did not affect satisfaction for these students could be that they were STEM students who expected the course to be challenging.

\section{RECOMMENDATIONS}

In the light of the findings drawn out by the researcher in this study the following suggestions and recommendations are offered:

School Administrators. To adopt online learning, greater attention must be paid to course structure design, which should be based on theories and previous research.

Instructors and Course Developer. To meet the aims of online learning platforms, instructors and course developers must be trained and skilled. Workshops and training sessions for both instructors and students are required for them to become more familiar with learning management systems such as Quipper and other LMS. The software alone is insufficient to create a proper online learning environment for students and teachers. The quality of education provided to students will be affected if teachers are not taught and are uninformed about using the software in the classroom. Training and evaluating the class teacher and implementing software changes could result in a positive learning environment for the instructor and high-quality education for the students. Students' pleasure and academic success are both influenced by their past knowledge and experience with online learning.

Students. Not just STEM students, but students in different fields must adapt to the ever-changing educational dynamics even if it is not a pandemic. Their cooperation alongside changes will help the teachers at the same time to be more inspired in developing tools that will increase learning satisfaction in online distance learning.

Future Researchers. Future researchers can use the data to look into the correlations between online learning qualities and student emotions and satisfaction, as well as the relationships between students' emotions and satisfaction.

\section{ACKNOWLEDGEMENT}

I, Orland Jae C. Jerusalem, would like to express my heartfelt gratitude to the following individuals who made a significant contribution to the success of this research paper. For his encouragement in completing this study, Dr. Ronald Decano, research adviser and Dean of Davao del Norte State College's Institute of Advanced Studies. The panel examiners, for their constructive criticism and suggestions which greatly aided in the improvement of this manuscript.

To my co-workers in The Rizal Memorial Colleges, Inc., Gel Marie B. Tiboron, for assisting me in completing this paper for publication. To the dearest validators, principal, and school director who approve my letter to let their school be my research environment. To my beloved parents and sisters for their love, understanding, support, and 
prayers; and above all, the Almighty Father, for the gift of life, knowledge, wisdom, good health, and blessings poured upon my family that made all things possible.

\section{REFERENCES}

1. Abernathy, D.J. (2020). what is e-learning? Retrieved at https://e-student.org/what-is-e-learning/. September 8, 2021.

2. Abuhassna, H. \& Al-Rahmi, W. M. (2020). Development of a new model on utilizing online learning platforms to improve students' academic achievements and satisfaction. Retrieved at https://educationaltechnologyjournal.springeropen.com/articles/10.1186/s41239-020-00216-z. December 18, 2021 .

3. (3)Al Othman, F.H.M. \& Shuqair, K.M. (2013). Effectiveness of the remedial courses on improving EFL/ESL students' performance at university level in the Arab world. http://dx.doi.org/10.5430/ijhe.v2n3p132 https://files.eric.ed.gov/fulltext/EJ1067409.pdf. September 8, 2021.

4. Al-Chibani (2014). The Effectiveness of Online and On-to-One Tutoring in the Writing Center on the Students' Achievement: A Multiple Case Study. DOI: 10.18052/www.scipress.com/ILSHS.41.192. December 18, 2021.

5. Almusharraf, N. \& Khahro, S. (2013). Students Satisfaction with Online Learning Experiences during the COVID19 Pandemic. Retrieved at https://online-journals.org/index.php/i-jet/article/view/15647/0. September 8, 2021.

6. AmbiLMS (2021). Online learning - why online classes are not effective. Retrieve at https://ambilms.com/onlinelearning-why-online-classes-are-not-effectivel. September 8, 2021.

7. Anderson, T. (2002). Towards a theory of online learning. Retrieved at https://ustpaul.ca/uploadfiles/DistanceEducation/TOWARDS_A_THEORY_OF_ONLINE_LEARNING.pdf. September 9, 2021.

8. Boitshwarelo, B., Reedy, A.K. Billany, T. (2017). Envisioning the use of online tests in assessing twenty-first century learning: a literature review. Retrieved at https://telrp.springeropen.com/articles/10.1186/s41039-0170055-7. December 18, 2021.

9. Boser, U. (2020). Everything you need to know about online tutoring. Retrieved at https://fordhaminstitute.org/national/commentary/everything-you-need-know-about-online-tutoring. December 18, 2021.

10. Bowers, J. (2015). Students' perceptions of teaching and social presence: a comparative analysis of face-to-face and online learning environments. Retrieved at https://www.igi-global.com/article/students-perceptions-ofteaching-and-social-presence/123160. September 6, 2021.

11. Bradley, V. M. (2021). Learning management system (LMS) use with online instruction. International Journal of Technology in Education (IJTE), 4(1), 68-92. https://doi.org/10.46328/ijte.36

12. Brady, A. M. (2005). Assessment of learning with multiple-choice questions. Nurse Education in Practice, 5(4), 238-242. December 18, 2021.

13. Bravo, M. R. P., Sibayan, A. L. (2019). An assessment of the e-learning management systems used by Philippine insurance agents of an international financial organization. Retrieved at https://www.dlsu.edu.ph/wpcontent/uploads/pdf/conferences/research-congress-proceedings/2019/lli-II-026.pdf. September 6, 2021.

14. Burgess, S. \& Sievertsen, H.H. (2020). Schools, skills, and learning: The impact of COVID-19 on education. Retrieved at https://voxeu.org/article/impact-covid-19-education. September 6, 2021.

15. Burns, M. (2020). Distance education for teacher training: modes, models, and methods. Retrieved at https://www.edc.org/sites/default/files/uploads/Distance-Education-Teacher-Training.pdf. September 9, 2021.

16. Business-Higher Education Forum (BHEF). 2005. A commitment to America's future: Responding to the crisis in mathematics and science education. Washington, DC: Business-Higher Education Forum. December 18, 2021.

17. Cahapay, M. B. (2020). Reshaping assessment practices in a Philippine teacher education institution during the coronavirus disease 2019 crisis. pedagogical research, 5(4), em0079. https://doi.org/10.29333/pr/8535 https://files.eric.ed.gov/fulltext/EJ1275525.pdf. September 6, 2021.

18. Cassady, J.C. \& Gridley, B.E. (2005). The effects of online formative and summative assessment on test anxiety and performance. Retrieved at https://files.eric.ed.gov/fulltext/EJ848518.pdf. September 6, 2021.

19. Cavanaugh, C. (2004). The effects of distance education on $k-12$ student outcomes: a meta-analysis. Retrieved at https://files.eric.ed.gov/fulltext/ED489533.pdf. September 6, 2021.

20. Cavrus, N. \& Sharif-Alhih, M. (2021). Learning management systems use in science education. DOI: https://doi.org/10.1016/j.sbspro.2014.07.429Get rights and content. December 18, 2021

21. Choe, R. C., Scuric, Z., Eshkol, E., Cruser, S., Arndt, A., Cox, R., Toma, S. P., Shapiro, C., Fitzgerald, M. L., Barnes, G. \& Crosbie, R. H. (2021). Student satisfaction and learning outcomes in asynchronous online lecture videos. Retrieved at https://www.lifescied.org/doi/10.1187/cbe.18-08-0171. September 6, 2021.

22. Chua, E. R., Sibbaluca, B. G., Miranda, R. D., Palmario, G. B., Moreno, R. P. \& Solon, J. P. T. (2020). The status of the implementation of the e-learning classroom in selected higher education institutions in Region IV-A midst the COVID-19 crisis. Retrieved at http://www.jcreview.com/fulltext/197-1590731776.pdf. September 9, 2021. 
23. Coman, C, Țîru, L.G., Schmitz, L.M., Stanciu, C. \& Bularca, M.C. (2020). Online teaching and learning in higher education during the coronavirus pandemic: students' perspective. Retrieved at https://www.mdpi.com/20711050/12/24/10367/htm. September 8, 2021.

24. EAPRO (2020). Guidance: assessing and monitoring learning during the covid-19 crisis. Retrieved at https://reliefweb.int/sites/reliefweb.int/files/resources/learning_assessments_during_covid-19_final.pdf. September 6, 2021.

25. Edwin, K. (2019). Reliability and validity of research instruments correspondence. Retrieved at https://www.researchgate.net/publication/335827941_Reliability_and_Validity_of_Research_Instruments_Corres pondence_to_kubaiedwinyahoocom. September 6, 2021.

26. Elsalem, L., Azzamb, N., Jum'ahc, A. A., Obeidat, N., Sindianid, M., \& Kheirallahe, A. (2020), Stress and behavioral changes with remote E-exams during the Covid-19 pandemic: A cross-sectional study among undergraduates of medical sciences. DOI: https://doi.org/10.1016/j.amsu.2020.10.058Get rights and content. December 18, 2021.

27. Elshami, W., Taha, M. H., Abuzaid, M., Saravanan, C., Al Kawas, S. \& Abdalla, M. E. (2021). Satisfaction with online learning in the new normal: perspective of students and faculty at medical and health sciences colleges. Retrieved at https://www.tandfonline.com/doi/full/10.1080/10872981.2021.1920090. September 6, 2021.

28. Engagement Theory. (2021). Retrieved at https://www.longdom.org/scholarly/engagement-theory-journalsarticles-ppts-list-2498.html. (2021). September 9, 2021.

29. (29)Europa, E. P. (2020). Academic facilities in the 'new normal'. Retrieved at https://www.manilatimes.net/2020/08/11/business/real-estate-and-property/academic-facilities-in-the-newnormal/753672. September 6, 2021.

30. Evran, A. \& Mahiro, A. (2016). School of public health, Georgia state university, Atlanta, GA, United States. Retrieved at https://files.eric.ed.gov/fulltext/EJ1117641.pdf. September 8, 2021.

31. Flaherty, C. (2020). Teaching lab sciences and the fine arts during COVID-19. Retrieved at https://www.insidehighered.com/news/2020/04/14/teaching-lab-sciences-and-fine-arts-during-covid-19.

September 6, 2021.

32. Foerderer, M., Hoffman, S., Schneider, N. \& Prichard, J.R. (2021). Predicting levels of student satisfaction during COVID-19. Retrieved at https://er.educause.edu/articles/2021/4/predicting-levels-of-student-satisfaction-duringcovid-19. September 6, 2021.

33. Fontaine, J. (2012). Online classes see cheating go high-tech. Chronicle of Higher Education, 58(38),A1-2. December 18, 2021.

34. Humphrey, E.A. \& Wiles, J.R. (2021). Lessons learned through listening to biology students during a transition to online learning in the wake of the COVID-19 pandemic. Retrieved at https://doi.org/10.1002/ece3.7303. September 6, 2021.

35. IGI Global (2020). What is learner satisfaction. Retrieved at https://www.igi-global.com/dictionary/learnersatisfaction/16784. September 6, 2021.

36. Ionescu, C.A., Paschia, L. \& Nicolau, N. L. (2020). Sustainability Analysis of the E-Learning Education System during Pandemic Period-COVID-19 in Romania. December 18, 2021.

37. Izhar, N. A., Al-dheleaI, Y. M. \& Na, K.S. (2021). Teaching in the time of COVID-19: The challenges faced by teachers in initiating online class sessions. Retrieved at https://hrmars.com/papers_submitted/9205/teaching-inthe-time-of-covid-19-the-challenges-faced-by-teachers-in-initiating-online-class-sessions.pdf. September 6, 2021.

38. (38)Jamal, H. \& Shanaah, A. (2011). The role of learning management systems in educational environments: an exploratory case study. Retrieved at https://www.diva-portal.org/smash/get/diva2:435519/FULLTEXT01.pdf. September 6, 2021.

39. Jiang, H., Islam, A. Y. M., Gu, X. \& Michael, J. (2018). Online learning satisfaction in higher education during the COVID-19 pandemic: A regional comparison between Eastern and Western Chinese universities. Retrieved at https://link.springer.com/article/10.1007/s10639-021-10519-x. September 6, 2021.

40. Johnson, E. (2017). What is 51talk? Retrieved at https://www.quora.com/What-is-51talk. September 6, 2021.

41. Kaya, S. (2015). Teachers' awareness and perceived effectiveness of instructional activities in relation to the allocation of time in the classroom. Retrieved at https://files.eric.ed.gov/fulltext/EJ1074871.pdf. September 6, 2021.

42. Loton, D., Stein, C., Parker, P. \& Gauci, S. (2021). Remote learning during COVID-19: Student satisfaction and performance Retrieved at https://edarxiv.org/n2ybd/download. September 7, 2021.

43. Mahajan, M. \& Singh, M. K. S. (2017). Importance and benefits of learning outcomes. Retrieved at http://www.iosrjournals.org/iosr-jhss/papers/Vol.\%2022\%20Issue3/Version-5/J2203056567.pdf. September 9, 2021. 
44. Mahmood, A., Mahmood, S. T., \& Malik, A. B. (2012). A comparative study of student satisfaction level in distance learning and live classroom at higher education level. Turkish Online Journal of Distance Education. Retrieved at https://eric.ed.gov/?id=EJ976935. September 7, 2021.

45. Mahyoob, M. (2020). Challenges of e-learning during the covid-19 pandemic experienced by EFL learners. Retrieved at https://files.eric.ed.gov/fulltext/EJ1287713.pdf. September 9, 2021.

46. Mateo, J. (2021). No face-to-face activities during remedial classes. Retrieved at https://www.philstar.com/headlines/2021/07/18/2113301/no-face-face-activities-during-remedial-classes.

September 7, 2021.

47. Rivera, C. (2013). Online remedial classes get an A for effort but need work. Retrieved at https://www.latimes.com/local/la-xpm-2013-jul-06-la-me-online-remedial-20130706-story.html. $\quad$ September 7, 2021.

48. Sinatra, G.M. \& Anderman, E.M. (n.d.) The Challenges of Teaching and Learning about Science in the 21st Century: Exploring the Abilities and Constraints of Adolescent Learners. Retrieved at https://sites.nationalacademies.org/cs/groups/dbassesite/documents/webpage/dbasse_072608.pdf. September 6, 2021.

49. Singh, V. (2019). Information and learning technol. Retrieved at https://iopscience.iop.org/article/10.1088/1757-899X/482/1/012008/pdf. September 6, 2021.

50. Uaminal, J.M. (2021). The students who are left behind: pandemic-induced gap year in the Philippines. Retrieved at https://asaa.asn.au/the-students-who-are-left-behind-pandemic-induced-gap-year-in-the-philippines/. September 6, 2021.

51. Vegas. E. (2020). School closures, government responses, and learning inequality around the world during COVID-19. Retrieved at https://www.brookings.edu/research/school-closures-government-responses-andlearning-inequality-around-the-world-during-covid-19/. September 6, 2021.

52. Verbosidad, A.B.C. (2019). The effectiveness of the remedial instruction in english at negros oriental state university bayawan-sta. catalina campus. Retrieved at https://research-manila.letran.edu.ph/read/164. September 6, 2021.

53. Waller, V., eLearning Network, and J. Wilson, The Forum for Technology in Training. Open and Distance Learning Quality Council (ODLQC). Newsletter. A Definition for E-Learning. December 18, 2021.

54. Watson, G., \& Sottile, J. (2010). Cheating in the digital age: Do students cheat more in online courses? Online Journal of Distance Administration, $13 \quad$ (1). Retrieved from http://www.westga.edu/ distance/ojdla/spring131/watson131.html. September 6, 2021.

55. Whitmer J.C. (2013). Logging on to improve achievement: Evaluating the relationship between use of the learning management system, student characteristics, and academic achievement in a hybrid large enrollment undergraduate course. Doctorate dissertation, university of California. USA. December 18, 2021.

56. Yearout Energy (2021). Preparing your school facility for the new normal. Retrieved at https://www.yearoutenergy.com/preparing-your-school-facility-for-the-new-normal/. September 6, 2021.

57. Yolak, B.B., Kiziltepe, Z, Seggie, F. N. (2013). The contribution of remedial courses on the academic and social lives of secondary school students. Retrieved at https://doi.org/10.1177/0022057419836434 https://journals.sagepub.com/doi/full/10.1177/0022057419836434. September 6, 2021

58. YuekMing, H. (2014). Assessing learning outcomes through students' reflective thinking. Retrieved at https://www.sciencedirect.com/science/article/pii/S1877042814054196. September 6, 2021

59. Zhao, Q., Long, J. \& Liu, S.H. A new type of remedial course for improving university students' learning satisfaction and achievement. Retrieved at

https://www.tandfonline.com/doi/full/10.1080/14703297.2021.1948886. September 6, 2021. 